\title{
Orson Welles: Ten Years After His Death
}

\author{
By Kevin Tierney
}

Fall 1995 Issue of KINEMA

ORSON WELLES ONCE REFLECTED on his own work in the following way: "Almost all serious stories in the world are stories of failure with a death in it. But there is more lost paradise in them than defeat." In many ways that could stand as the story of Orson Welles himself -- failure, death and lost paradises are serious stuff to be sure; but in speaking of a man who changed forever the way we look at movies, should we not speak of found paradises as well as lost, of victories and defeats?

With his passing in October of 1985, the most obvious temptation is to do to his death what Welles himself did to his most famous creation, Charles Foster Kane: ignore the warnings of NO TRESPASSING and plunge into the biographical details of what no doubt was a fascinating but ultimately tragic life, not unlike that of what we've come to recognize as the archetypal Welles hero.

For whether we think of Welles as Kane or Arkadin; Franz Kindler or Colonel Harky; Harry Lime or Michael O'Hara; Macbeth, Othello or even Falstaff, we are seeing parts of the kaleidoscopic prism of what was a cinematic genius whose decline was not only inevitable given the nature of his relationship with Hollywood moguls and some of their foreign cousins with whom he would deal later on; but perhaps even necessary -in order for Welles to play out the role he seemed to believe fate had saddled him with -- a kind of inspired affliction.

Like Kane's whisper of Rosebud, that which had determined his life, Welles' life began with the whisper of a word that would act similarly on him -- genius. The whisperer was a Dr. Bernstein, a peculiar figure who, apart from being the family doctor, was also having an affair with Welles' mother, and he was to have an enormous influence on young Orson. Later Welles would immortalize the name by giving it to the only person who remains loyal to Charles Kane. Genius or not, Welles was at the very least precocious, if not an outright prodigy, and apparently deserving of all the special attention he received.

Like the quintessential precocious child he was, he demanded special treatment, received it and demanded more. But unlike other "special" children who turn into boring brats, Welles managed to transcend the pitfalls through a combination of will, arrogance, determination and above all, talent. Ironically, in doing so he created an aura of mythology around himself that might be the envy of any of his tragic personae.

On a painting tour of Ireland at age 16, he walked his way onto the stage of Dublin's Gate Theatre where he began a relationship with the co-founders of the theatre, Hilton Edwards and Micheal MacLiammoir, whose separate talents would have profound influences on the multi-talented young man. Edwards's sense of what theatre should be later found its way into Welles' innovative stage productions, while MacLiammoir's acting style no doubt rubbed off on Welles' considerable talents in front of the camera.

Many years later, the same MacLiammoir would be cast by an older Welles to play Iago to his Othello and would document the unique experience of making Wellesian cinema in a book entitled Put Money In Thy Purse, a sometimes hilarious and always insightful record of Welles rushing off to act in other people's movies all over Europe in order to help finance his struggling production of Othello. Set in the Spanish moors, ${ }^{(1)}$ with an international cast of actors and financiers, the film took four years to complete.

Upon his return to America at the ripe old age of 21, Welles soon took the New York stage by storm with among others, a strikingly bold production of a voodoo-inspired Macbeth set in Harlem. A similar phenomenon occurred when he began his radio work, including the by now legendary broadcast of War of the Worlds ${ }^{(2)}$, which had thousands of listeners utterly convinced that Martians had actually invaded the United States. In a few short years Welles was the highest paid voice on radio and even after moving to California he regularly commuted to New York to do his radio show. As a result, his move to California in 1940 was on the one hand nothing more or less than the logical American evolution from stage to screen. On the other hand, however, there was also one of the most hyped up contracts ever -- the first time a studio would offer full control, including final cut, to a first time director. 
In the cinema Welles found a home for his numerous talents -- his youthful face and big leading man features; a voice that could command and seduce almost simultaneously; and a vision of what movies could do to the ancient art of storytelling. Instinctively he seemed to recognize that film was not a medium for ideas, it was a means for affecting the emotions. "You could write all the IDEAS of all the movies, my own included, on the head of a pin," Welles told his biographer, Barbara Leaming. "It's a form that may grip you or take you into a world or involve you emotionally -- but ideas are not the subject of films."

But Hollywood also presented Welles with a pathetic irony he struggled against for decades after Kane but was finally defeated by. It was one thing to make movies about heroic individualists whose tenaciousness changed the course of history, that was what American movies did best -- mythologize the people and the country. But you weren't supposed to actually believe that the studio heads were prepared to treat you that way. No, the reality was very different and the only way Welles could remain there comfortably in the latter part of his life was to become a kind of parody of himself, a blimpish fixture on the talk show scene; the odd cameo appearance in movies whose only saving grace was his presence; and those awful wine commercials that filled the American airwaves before sophisticated fat gave way to elegant thin and Welles was replaced as the spokesman by John Gielgud, a man whose very best film performance came as the cold embittered King Henry IV in Chimes at Midnight, directed by none other than Orson Welles. Poor old Falstaff defeated again by royalty.

The movies didn't defeat Orson Welles but the deals did. In his time he had worked hard to produce in the style and within the limitations of the system. The Stranger (1946) is perhaps the worst example of these efforts. Produced by Sam Spiegel when he still called himself S. P. Eagle from a script by Anthony Veiller, longtime friend John Huston and Welles himself, it's a melodramatic paranoid fantasy of an untried Nazi war criminal who escapes Europe after the war and assumes a new identity in a sleepy American town. The tone of the movie is near hysteria and for the second time in three tries at Hollywood movie making, Welles was not allowed control over the production.

Yet, Lady from Shanghai (1949) and Touch of Evil (1956), neither of which bear his final cut, remain splendid examples of Welles' peculiar vision of American movie genres on one level, while on another he seems to be enjoying biting the hand that fed them. Whether or not Welles consciously set out to undermine the various precepts of Hollywood filmmaking in these two movies can at this point only be speculated upon, but looking at them today one can't help but be struck by the extraordinary tightrope walking Welles managed.

In Lady from Shanghai he used the considerable talents of his wife of the day, Rita Hayvorth, to offer a wonderfully cynical allegory of beauty and seduction -- the very stuff Hollywood movies are made of. Nearly ten years later, the prodigy turned prodigal returned once again and turned the town on its ear with Touch of Evil, a virtuoso piece of filmmaking that not only reinforced Welles' critical following, but in its casting, conception and realization showed Welles the director at peak form, completely in control of his medium.

As the slobby, vile-looking Captain Quinlan, Welles gives an extraordinary performance, his make-up alone saying reems about corruption. Marlene Dietrich as the Gypsy-dressed Madame in the Mexican bordertown resonates as a character out of film history, while Janet Leigh in panties and bra is into weird things with Dennis Weaver in an isolated motel room two full years before she runs into Anthony Perkins in Hitchcock's Psycho.

The opening and closing sequences of Touch of Evil are essential viewing for anyone aspiring to use a movie camera. Although initially he was reluctant to take on the project, Welles managed to render unto Caesar a commercial property worthy of their investment, while simultaneously giving audiences what he was best at -- spectacle and speculation on the form of film itself.

Welles' oeuvre is far from a consistent one. How could it be given all the places he worked and all the investors, distributors and exhibitors he was forced to turn to? One suspects, however, that if the films were screened the way their director originally intended, a fuller, more honest portrait would emerge.

The Magnificent Ambersons (1942) was his first "film maudit" but certainly not his last. Approximately 45 minutes were removed from Welles' nostalgic tribute to the past yet it still managed to rate eighth place in a 1972 poll conducted by the British Film Institute journal Sight and Sound, the eighth best film of all time! 
On three separate occasions Welles brought the works of William Shakespeare to the screen and on each occasion it was accompanied by some startling revelation or insight into either the text or the art of film. More often than not, both.

Macbeth (1948) was shot in 23 days, an experiment Welles hoped would encourage other filmmakers to take on difficult subjects at greater speeds. Far from being slavish to the printed word, he celebrated his departures from the Bard as well as from Kafka in The Trial (1962) but always with the same goal in mind, to be true to the spirit of the originals. Criticized for his tampering with Othello (1951), he later turned to the character of Falstaff in Chimes at Midnight (1965/66). A recurring character in no less than five plays, Welles wove together a memorable portrait of an adult's conception of Santa for which he was awarded a special XXth Anniversary Prize by the jury of the 1966 Cannes Film Festival.

Like virtually all of Welles' films, Chimes at Midnight reflects what may be the single most important Wellesian metaphor, the frog and the scorpion. It lies at the heart of what is Welles' most personal film, Confidential Report/Mr. Arkadin (1955). Adapted from his novel which had been published in France in 1952, it sets out to be the story of Gregory Arkadin's quest for his own lost identity but ultimately seems to be more about a vicious and desperate man's attempt to erase his past in order to be worthy of his daughter's love.

At a party in the protagonist's Spanish castle, Arkadin tells some of his guests a fable. A scorpion, who could not swim, approached a frog and pleaded with him to carry him on his back to the other side of a stream. The frog was reluctant, given the scorpion's reputation for stinging its victims. The scorpion calmed the frog's fears by pointing out to him that if he were to sting the frog, he, too, would drown. The frog accepted and halfway across he felt a piercing pain in his back where the scorpion had stung him. "Is that logic?" screamed the frog. "No, it's not," replied the scorpion, "but I can't help it. It's my character."

To Welles, the point of the fable is "to show that a man who declares himself in the face of the world, I am as I am, take it or leave it, that this sort of man has a tragic dignity."

In this, Arkadin can be seen to share an element of tragic dignity with all the other scorpions of Welles' world -- Kane, Georgie Minafer, Franz Kindler, Mr. and Mrs. Bannister, Macbeth, Iago, Captain Quinlan and Falstaff's stinger, Prince Hal. What elevates Welles above other filmmakers, however, was his ability to convey with equal ease the humanity of the frog, from the loveable Falstaff to the entire supporting cast of Citizen Kane. To Welles' enormous credit, the characterizations of the metaphor were never over-simplified into some banal demonstration of good and evil, nor were his audiences allowed the comfort of disappearing behind the veil of artificial "reality" that tended to characterize much of the Hollywood production of Welles' peers.

And then there was Kane. And then there was always Kane, or so it seemed to be. He was only 26 years old when he co-wrote, directed, produced and starred in what was to become the most written about film in the history of cinema. Any of these creative hats would have been enough burden for anyone let alone an upstart theatre director and radio voice. But for Welles, it was nothing more or less than he had been doing in his New York Mercury productions. Except that now there was the camera. "A film is never really good unless the camera is an eye in the head of a poet," Welles once wrote in a letter to a newspaper. And therein lies a fair description of what seemed so powerful in 1941 and today seems extraordinary.

The startling techniques -- editing, deep focus, over-lapping sound, the use of music, the presence of ceilings -- remain quite startling but time has eroded much of their shock value. Today's audiences tend to respond more to the truth of the media-led hunt than to the flash and panache of the style. What remains is the strength of the drama and above all, the characters, none more so than Kane himself.

Only such an important film could cause as much controversy as it has, from the months leading up to its release through to today. In the beginning it was the notion that the character of Kane was scandalously close to press baron William Randolph Hearst. Much later the discussion centred around how much credit for the creation should go to Welles and how much should be given to Herman J. Mankiewicz, the two people who shared the screen credit. Ironically both controversies ended up looking like scenes out of Orson Welles' movies, though there is little doubt but that Welles was hurt by the aspersions about his contributions cast by people like New Yorker magazine critic, Pauline Kael. 
Shortly before his death on October 10, 1985, three new books on Orson Welles were published in the United States, two of them biographies and the third yet another exhaustive analysis of who wrote Citizen Kane. Positive or negative -- and each biography might be thought to represent such sentiments -- these books reaffirm the interest in Welles' life and work. Perhaps their appearance was sufficient vindication for Welles to use them as his exit cue, though he might have wished to see himself at work on one of the numerous film projects with which he had been associated in the last years of his life.

There was talk of a filmed version of King Lear and one day we might get to see some of The Other Side of the Wind, a film about a famous Hollywood director, starring John Huston, that was shot over a period of years in the 1970s. Unfortunately that footage remains tied up in the financial hands of one of Welles' last financial backers, the brother-in-law of the former Shah of Iran.

With Welles' death comes the opportunity to call a temporary halt to the speculation about why he stopped making movies. In its place we have the singular pleasure of seeing what he left us, a relatively small but thoroughly engrossing body of work that will always be respected and re-viewed no matter what the personal shortcomings of its maker are calculated to be. For in each Orson Welles movie we find or re-discover a lost paradise while their totality represents the victory of the artist's vision.

Editor's Note:

On this anniversary of his death, Welles' presence is still felt on the screen in many forms. The latest is the recent German-French-Swiss film The One-Man Band directed by Vassili Silovic (1995) and made possible by Oja Kodar. According to David Stratton in Variety that for Orson Welles' buffs, this film "will be the most exciting experience in years." It consists almost entirely of material directed by Welles that has never been publicly presented before.

\section{Notes}

1. The legendary city of Mogador, today's Essaouira, Morocco.

2. Adapted from the novel by H. G. Wells.

\section{References}

\section{Orson Welles Filmography}

1934: The Hearts of Age (16mm short, co-d)

1938: Too Much Johnson (+co-pr, script)

1941: Citizen Kane

1942: The Magnificent Ambersons

1943: Journey into Fear (co-d, co-sc)

1946: The Stranger

1948: The Lady from Shanghai; Macbeth

1952: Othello

1955: Mr. Arkadin (Confidential Report)

1958: Touch of Evil

1962: The Trial

1966: Chimes at Midnight (Falstaff)

1968: The Immortal Story

1970: The Deep

1972: The Other Side of the Wind (incomp.)

1975: F for Fake

\section{Literature}

Bazin, André. Orson Welles. Paris: Edition Chavane, 1950. 
Bogdanovich, Peter. The Cinema of Orson Welles. New York: Film Library of MOMA, 1961.

Carringer, Robert L. The Making of Citizen Kane. Berkeley: University of California Press, 1985.

The Citizen Kane Book. Boston: Little, Brown, 1971.

Comito, Terry. Touch of Evil. Rutgers State University, 1985.

Cowie, Peter. The Cinema of Orson Welles. New York: A.S. Barnes, 1965.

Gottesman, Ronald, ed. Focus on Citizen Kane. Englewood Cliffs: Prentice-Hall, 1971.

Higham, Charles. The Films of Orson Welles. Berkeley: University of California Press, 1971. . Orson Welles, the Rise and Fall of American Genius.

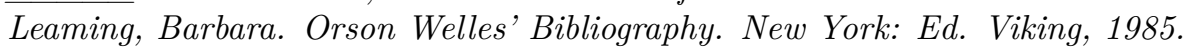

McBride, Joseph. Orson Welles. New York: Ed. Viking, 1972.

Naremore, James. The Magic World of Orson Welles. New York: Oxford University Press, 1978.

"Orson Welles." Cahiers du cinéma. Hors-série No. 12. Paris: Ed. de l'Etoile, 1982.

Parra, Danièle et Jacques Zimmer. Orson Welles. Paris, 1985. 